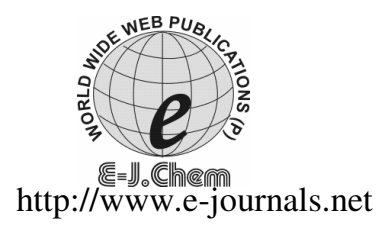

ISSN: 0973-4945; CODEN ECJHAO

E-Journal of Chemistry

2009, 6(S1), S211-S218

\title{
Hydrochemical Characteristics and Evaluation of Groundwater Quality of Tumkur Amanikere Lake Watershed, Karnataka, India
}

\author{
D S. RAJENDRA PRASAD ${ }^{*}$, C. SADASHIVAIAH and G. RANGNNA ${ }^{\S}$ \\ *Department of Civil Engineering, S.I.T., Tumkur -572103, \\ Karavali Institute of Technology, Neer Marga, Mangalore-29, India. \\ ${ }^{\S}$ Visiting Professor, UGC-CSA, Department of Mathematics, \\ Central College Campus, Bangalore University, Bangalore, India. \\ dsrajendraprasad@yahoo.co.in
}

Received 24 April 2009; Accepted 15 June 2009

\begin{abstract}
The study area, Tumkur amanikere lake watershed, is located $0.5 \mathrm{~km}$ away from Tumkur Town on National Highway No.4. The main source of water for this lake is Kallur village tank catchment area. The average rainfall in the area is 965 $\mathrm{mm}$. The submersion area of the lake at MWL is 204 hectares. Groundwater samples were collected from 22 stations covering the area during the year 2008 and were analyzed for physicochemical characters. The type of water that predominated in the study area is $\mathrm{Ca}-\mathrm{Mg}-\mathrm{Cl}$ type, was assessed based on hydrochemical facies. Besides, suitability of groundwater for irrigation was evaluated based on sodium adsorption ratio, percent sodium, and the US salinity diagrams.
\end{abstract}

Keywords: Groundwater, Chemical classification, Physicochemical characters, SAR, USSL diagram

\section{Introduction}

The physical and chemical parameters of groundwater play a significant role in classifying and assessing water quality. The hydrochemical study reveals quality of water that is suitable for irrigation, agriculture, drinking and industrial purposes. It was observed that the criteria used in the classification of waters for a particular purpose may not find the suitability standards for other purposes and better results can be obtained only by considering the combined chemistry of all the ions rather than individual or paired ionic characters ${ }^{4-6}$. Chemical classification also throws light on the concentration of various predominant cations, anions and their interrelationships. Considering the individual or paired ionic concentration, certain indices to find out the alkali hazards were proposed ${ }^{1-3}$. A number of techniques and methods have been developed to interpret the chemical data. Zaporozec ${ }^{7}$ summarized the various modes of data representation and discussed their possible uses.

Presentation of chemical analysis in graphical form makes understanding of complex groundwater system simpler and quicker. Methods of representing the chemistry of water like Collin's bar diagram ${ }^{6}$, radiating vectors of Maucha ${ }^{8}$ and parallel and horizontal axes of Stiff ${ }^{9}$, have 
been used in many parts of the world to show the proportion of ionic concentration in individual samples. Balasubramanian ${ }^{10}$ and Subramanian ${ }^{11}$ followed a series of methods to interpret and classify the chemistry of groundwater in hard rock, including coastal zones in the southern parts of India.

The objective of the present work is to discuss the major ion chemistry of Tumkur amanikere lake watershed groundwater. In this case the methods proposed by Piper $^{12}$, Back and Hanshaw ${ }^{13}$, Wilcox ${ }^{14}$, Eaton $^{3}$, Todd ${ }^{15}$ and USSL (US Salinity Laboratory) classifications ${ }^{16}$ have been used to study critically the geo-chemical characteristics of the groundwater of Tumkur Amanikere lake watershed.

\section{Salient features of the study area}

The area under study is Tumkur Amanikere lake watershed is located $0.5 \mathrm{~km}$ away from Tumkur Town on National Highway No.4. Tumkur town is $70 \mathrm{~km}$ away from the capital city Bangalore. The location of the lake is: latitude $13^{\circ} 26^{\prime} 35^{\prime \prime}$ and longitude is $77^{\circ} 06^{\prime} 30^{\prime \prime}$. The population of the town is $2,48,000$ (2001 census). The main occupation of Tumkur district population is agriculture and horticulture. It is also one of the major educations, small \& medium sized industrial centers in Karnataka.

The main source of water for this lake is Kallur village lake catchment area. The catchment area of this lake is $31.86 \mathrm{sqkm}$ and intercepted catchment area is $5.60 \mathrm{sqkm}$. It is located in the sub basin of river shimsha and main basin of Cauvery. The average rainfall in the area is $965 \mathrm{~mm}$. The submersion area of the lake at MWL is 204 hectares. The Yield of the lake is 7.95MCUM and Water Gross Utilization is 5.14MCUM. The gross commanding area (GCA) is 334 hectares. Occurrence, movement and storage of groundwater are influenced by lithology, thickness and structure of rock formations. Weathered and fractured granites, granitic gneiss form the main aquifer in Tumkur, Taluk. Ground water in the study area occurs under water table conditions in the weathered and fractured granite, Gneisses. There is no perennial river in the study area. The general type of soil of the commanding area is: loamy sand. The location map of Tumkur Amanikere lake watershed is shown in Figure 1. The major ion chemistry of groundwater of Tumkur amanikere lake watershed has not been studied earlier.

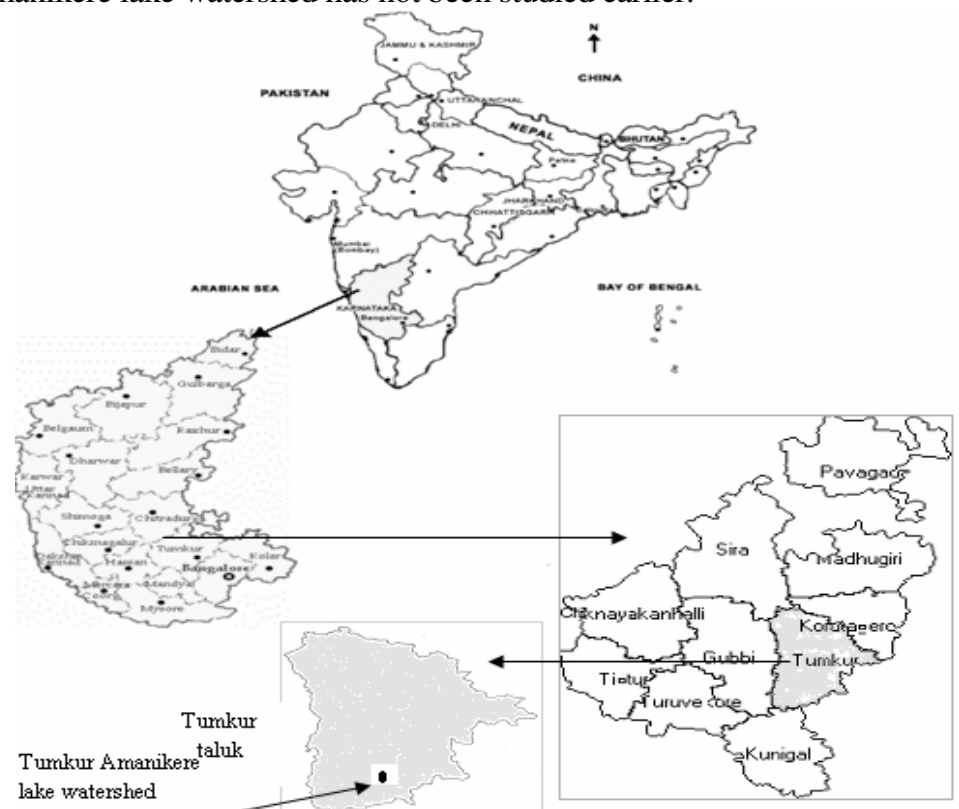

Figure 1. Map showing the location of Tumkur taluk and Tumkur Amanikere lake watershed. 


\section{Methodology}

Groundwater samples were collected from 22 locations from Tumkur amanikere lake watershed (during Jan - February 2008). The collected water samples were transferred into precleaned polythene container for analysis of chemical characters. Chemical analyses were carried out for the major ion concentrations of the water samples collected from different locations using the standard procedures recommended by APHA- $1994^{18}$. The analytical data can be used for the classification of water for utilitarian purposes and for ascertaining various factors on which the chemical characteristics of water depend.

\section{Results and Discussion}

Major and minimum concentration of major ions present in the groundwater is shown in Table 1. The chemical characteristics (Sawyer and McCarthy Hardness, and \% $\mathrm{Na}$ ) of groundwater in the study areas are listed in Tables $2 \& 3$. All the water samples in the study area fall under hard to very hard water category as per Sawyer and Mc Crathy's classification. The classification with respect to percent sodium shows that 14 samples are in excellent range and remaining fall in good and permissible range.

Table 1. Maximum and minimum concentration of major ions in Tumkur Amanikere lake watershed samples

\begin{tabular}{ccc}
\hline Ions & Minimum, $\mathrm{mg} / \mathrm{L}$ & Maximum, $\mathrm{mg} / \mathrm{L}$ \\
\hline $\mathrm{Na}^{+1}$ & 8 & 48 \\
$\mathrm{~K}^{+1}$ & 0.2 & 4.0 \\
$\mathrm{Ca}^{+2}$ & 14.03 & 98.6 \\
$\mathrm{Mg}^{+2}$ & 38.88 & 150.7 \\
$\mathrm{HCO}_{3}^{-1}$ & 185 & 436 \\
$\mathrm{Cl}^{-1}$ & 62.38 & 255.9 \\
$\mathrm{SO}_{4}^{-2}$ & 0.0 & 57.0 \\
\hline
\end{tabular}

Table 2. Classification of water based on total hardness by Sawyer and Mc Carthy.

\begin{tabular}{ccc}
\hline Total Hardness as $\mathrm{CaCO}_{3}, \mathrm{ppm}$ & Water class & Number of samples \\
\hline $0-75$ & Soft & 0 \\
$75-150$ & Moderate Hard & 0 \\
$150-300$ & Hard & 7 \\
$>300$ & Very Hard & 15 \\
\hline
\end{tabular}

Table 3. Classification of water samples based on sodium percent.

\begin{tabular}{cccc}
\hline Sodium, $\%$ & Water class & Number of samples & Remarks \\
\hline$<20$ & Excellent & 14 & Value varies between $9.13-19.31$ \\
$20-40$ & Good & 6 & Value varies between 20.92-39.64 \\
$40-60$ & Permissible & 2 & Value varies between $40.75-40.95$ \\
$60-80$ & Doubtful & 0 & \\
$>80$ & Unsuitable & 0 & \\
\hline
\end{tabular}

The sodium in irrigation waters is usually denoted as percent sodium and can be determined using the following formula ${ }^{14}$,

$$
\% \mathrm{Na}=\left(\mathrm{Na}^{+}\right)^{\prime} 100 /\left(\mathrm{Ca}^{2++} \mathrm{Mg}^{2+}+\mathrm{Na}^{+}+\mathrm{K}^{+}\right)
$$

Where, the quantities of $\mathrm{Ca}^{2+}, \mathrm{Mg}^{2+}, \mathrm{Na}^{+}$and $\mathrm{K}^{+}$are expressed in milliequivalents per litre (epm). The classification of groundwater samples with respect to percent sodium and EC is shown in Figure 2. 
Electrical Conductivity in $\mathrm{ms} / \mathrm{cm}$
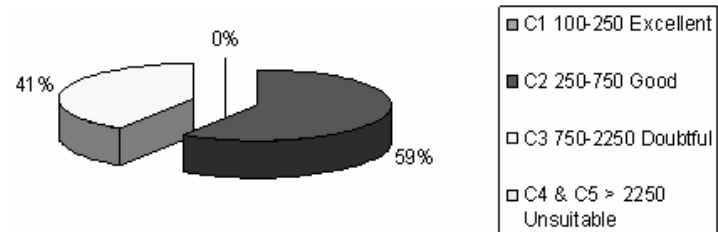

Figure 2. Classification of water based on salinity hazard.

Table 4. Characterization of groundwater of Tumkur Amanikere Lake Watershed on the basis of Piper Tri-Linear diagram.

\begin{tabular}{clc}
$\begin{array}{c}\text { Subdivision of } \\
\text { the diamond }\end{array}$ & \multicolumn{1}{c}{$\begin{array}{c}\text { Characteristics of corresponding subdivision of } \\
\text { diamond - shaped fields }\end{array}$} & $\begin{array}{c}\text { Percentage of samples } \\
\text { in this category }\end{array}$ \\
\hline 1 & Alkaline earth $(\mathrm{Ca}+\mathrm{Mg})$ Exceed alkalies $(\mathrm{Na}+\mathrm{K})$ & 90 \\
2 & Alkalies exceeds alkaline earths & 10 \\
3 & Weak acids $\left(\mathrm{CO}_{3}+\mathrm{HCO}_{3}\right)$ exceed Strong acids $\left(\mathrm{SO}_{4}+\mathrm{Cl}\right)$ & 10 \\
4 & Strong acids exceeds weak acids & 90 \\
5 & Magnesium bicarbonate type & 13.6 \\
6 & Calcium-Chloride type & 13.6 \\
7 & Sodium-Chloride type & 0 \\
8 & Sodium-Bicarbonate type & 0 \\
9 & Mixed type (No cation-anion exceed 50\%) & $72 \%$ \\
\hline
\end{tabular}

The Piper-Hill diagram ${ }^{12}$ is used to infer hydrogeochemical facies. These plots include two triangles, one for plotting cations and the other for plotting anions. The cation and anion fields are combined to show a single point in a diamond-shaped field, from which inference is drawn on the basis of hydrogeochemical facies concept ${ }^{13}$. These tri-linear diagrams (Figure 3) are useful in bringing out chemical relationships among groundwater samples in more definite terms rather than with other possible plotting methods is presented in Table 4.

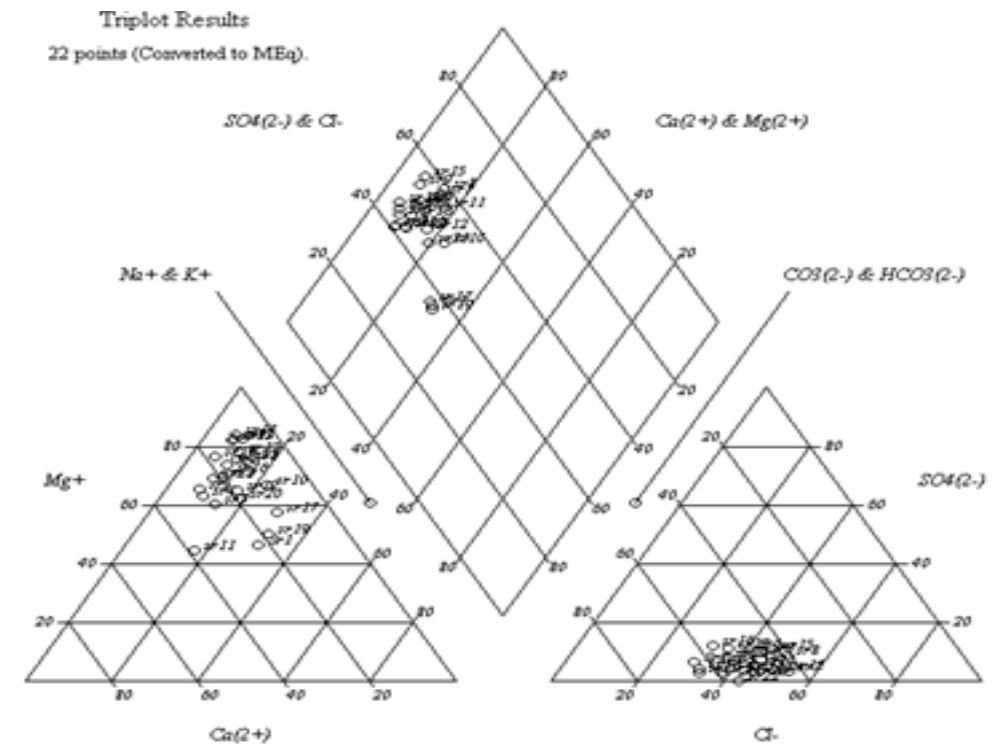

Figure 3. Tumkur Amanikere Lake Watershed Water samples plotted in Piper-Tri-linear diagram. 
The concept of hydrochemical facies was developed in order to understand and identify the water composition in different classes. Facies are recognizable parts of different characters belonging to any genetically related system. Hydrochemical facies are distinct zones that possess cation and anion concentration categories. To define a composition class, Back and co-workers 13, 29 suggested subdivisions of the tri-linear diagram (Figure 4). The interpretation of distinct facies from the 0 to $10 \%$ and 90 to $100 \%$ domains on the diamondshaped cation to anion graph is more helpful than using equal $25 \%$ increments. It clearly explains the variations or domination of cation and anion concentrations.

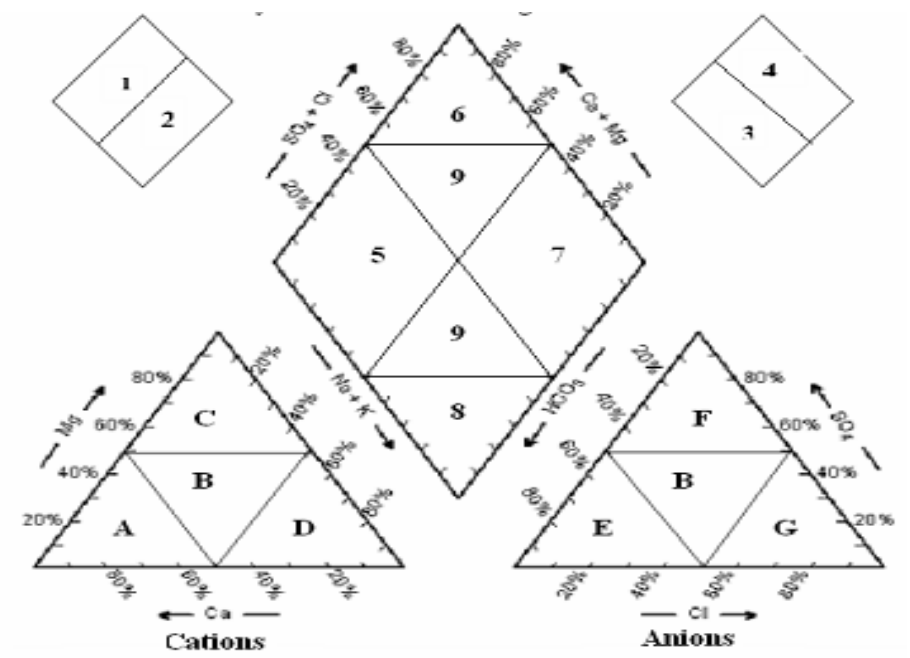

Legend: A-Calcium type, B-No Dominant type, $C$ - Magnesium type, D-Sodium and potassium type, E-Bicarbonate type, $F$-Sulphate type, G-Chloride type.

Figure 4. Classification diagram for anion and cation facies in the form of major-ion percentages. Water types are designed according to the domain in which they occur on the diagram segments.

Mg-type of water is predominated. The percentage of samples falling under Mg-type was 90. For anion concentration, Cl-Bicarbonate type of water predominated with $32 \%$ samples and remaining $68 \%$ is no dominant type. There is no significant change in the hydro-chemical facies noticed that most of the major ions are natural in origin. The reason is groundwater passing through igneous rocks dissolves only small quantities of mineral matters because of the relative insolubility of the rock composition. The US Salinity Laboratory (USSL) of the Department of Agriculture adopted certain techniques based on which the suitability of water for agriculture is explained ${ }^{16}$.

The most important characteristics of irrigation water in determining its quality are: (i) Total concentration of soluble salts; ii) Relative proportion of sodium to other principal cations; (iii) Concentration of boron or other element that may be toxic, and (iv) Under some condition, bicarbonate concentration as related to the concentration of calcium plus magnesium. These have been termed as the salinity hazard ${ }^{17}$, sodium hazard, boron hazard and bicarbonate hazard. In the past, the sodium hazard has been expressed as per cent sodium of total cations. A better measure of the sodium hazard for irrigation is the SAR which is used to express reactions with the soil. SAR is computed as where all ionic concentrations are expressed in epm.

The classification of water samples based SAR as per US Salinity (USSL) for irrigation purposes is shown in Table 5. It is observed that all the samples are fall in excellent class. The equation for SAR is given below:

$$
\mathrm{SAR}=\mathrm{Na}^{+} /\left(\left(\mathrm{Ca}^{2-}+\mathrm{Mg}^{2+)} / 2.0\right)^{1 / 2}\right.
$$


Table 5. Classification of water samples based on USSL Sodium hazard for irrigation purposes.

\begin{tabular}{cccc}
\hline Sodium hazard class & SAR in Equivalent per mole & Water class & Number of samples \\
\hline S1 & $<10$ & Excellent & 22 \\
S2 & $10-18$ & Good & 0 \\
S3 & $18-26$ & Doubtful & 0 \\
S4 \& S6 & $>26$ & Unsuitable & 0 \\
\hline
\end{tabular}

When SAR and Specific conductance of water known, the classification of water for irrigation can be determined by graphically plotting SAR and EC values on US Salinity (USSL) diagram as shown in Figure 5. About $60 \%$ of samples are fall in C2S1 and C3S1 classes.

For the purpose of diagnosis and classification, the total concentration of soluble salts (salinity hazard) in irrigation water can be expressed in terms of specific conductance. Classification of groundwater based on salinity hazard is presented in Table 6 . It is found from the EC value, 13 samples are good and 9 samples are in doubtful range for irrigation purposes.

Table 6. Classification of water samples based on salinity hazard.

\begin{tabular}{cccc}
\hline Salinity hazard class & EC in $(\mathrm{ms}-\mathrm{cm})$ & Water class & Number of samples \\
\hline C1 & $100-250$ & Excellent & 0 \\
C2 & $250-750$ & Good & 13 \\
C3 & $750-2250$ & Doubtful & 9 \\
C4 \& C5 & $>2250$ & Unsuitable & 0 \\
\hline
\end{tabular}

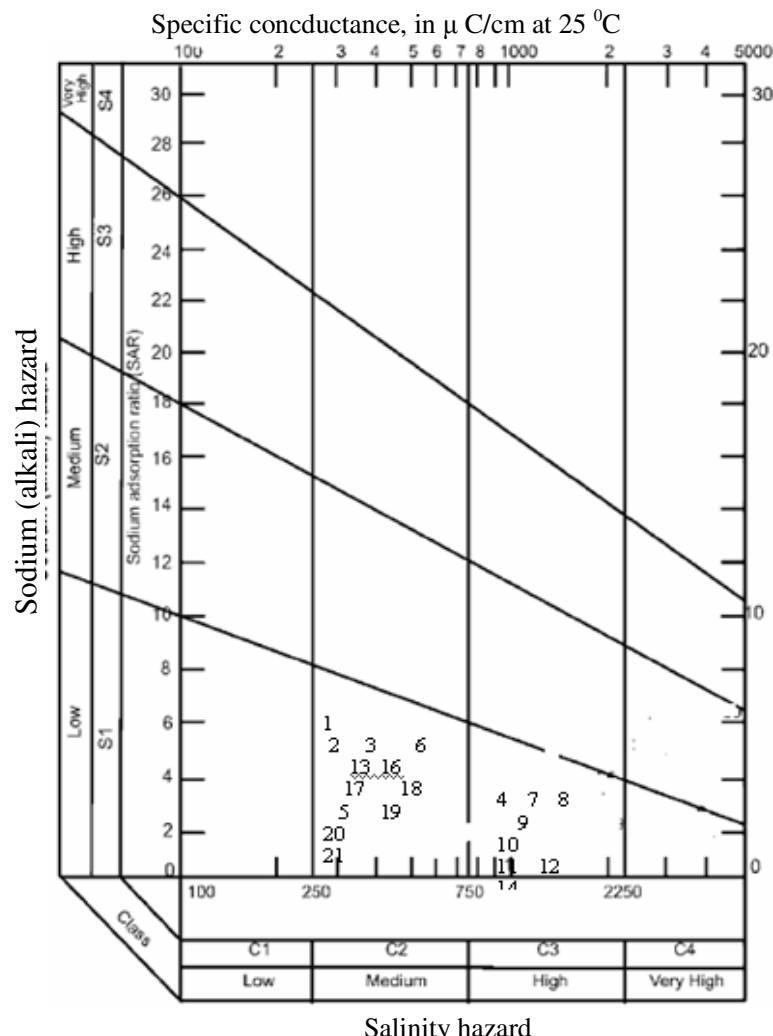

Figure 5. US Salinity diagram of Tumkur Amanikere lake watershed samples. 
Progressive changes in the geochemical characters of a large numbers of samples can best be studied by plotting selected constituents on bi-linear and tri-linear diagrams. Such diagrams can show the relation between concentrations of various constituents or groups of constituents. Thus, on a two-coordinate field, the relation between the concentrations of calcium, magnesium, sodium, bicarbonates, chloride etc, and TDS can be studied as shown in Figure 6.

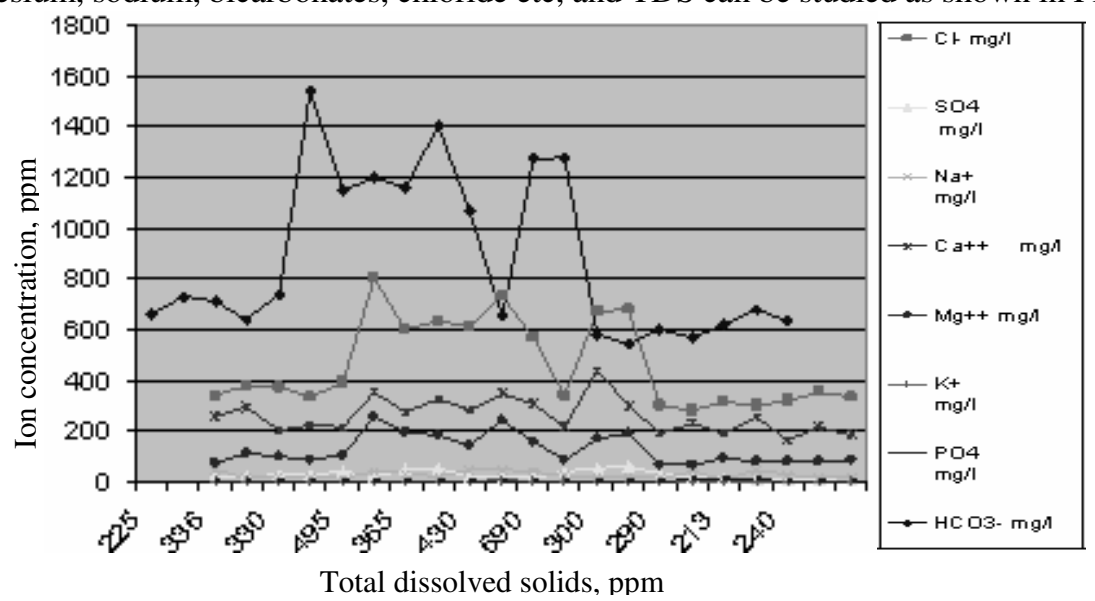

Figure 6. Relation between $\mathrm{Cl}, \mathrm{SO}_{4}, \mathrm{Na}, \mathrm{Mg}, \mathrm{K}, \mathrm{PO}_{4}, \mathrm{HCO}_{3}$ and TDS.

\section{Conclusions}

1. The type of water predominates in the study area is $\mathrm{Ca}-\mathrm{Mg}-\mathrm{Cl}$ type. This may be mainly due to the geology of the area which comprises igneous rocks of crystalline nature, in which the major units are gneisses and granites.

2. Though the suitability of water for irrigation is determined based on SAR, $\% \mathrm{Na}$ and Salinity hazard, it is only empirical conclusion. In addition to water quality, other factors like soil type, crop type, crop-pattern, frequency and recharge (rainfall), climate etc., have an important role to play in determining the suitability of water.

3. Water that is not suitable on the above classification may be suitable in welldrained soils.

4. The suitability of water for irrigation is evaluated based on SAR, \% Na and salinity hazards. Most of the samples in Tumkur Amanikere watershed fall in the suitable range for irrigation purposes either from SAR or $\% \mathrm{Na}$ values.

5. It is observed from the US Salinity classification of water samples for irrigation purposes that, all the samples are fall in excellent class.

6. It is found from the classification of water samples based on total hardness, most of the samples are categorized under hard and very hard.

\section{Acknowledgement}

The authors wish to place on record their sincere thanks to Dr. S M Shashidhara principal, SIT, Tumkur and Dr. M.N. Channabasappa, Director, SIT, for providing facilities to prepare this paper. Many thanks are extended to Dr. P.H. Shivapraksh, Head, Department of Civil Engineering, SIT, for his encouragement during the development of this paper.

\section{References}

1. Kelley W P, Permissible composition and concentration of irrigation water. Proc ASCE, 1940, 66, 607. 
2. Wilcox L V, The quality water for irrigation use, US Dept Agric Bull., 1948, 1962, 40.

3. Eaton E M, Soil Sci., 1950, 69, 123-133.

4. Handa B K, Soil Sci., 1964, 98, 264-269.

5. Handa B K, Curr Sci., 1965, 34, 313-314.

6. Hem J D, Study and interpretation of the chemical characteristics of natural water, USGS Water Supply Paper, 1985, 2254, 117-120.

7. Zaporozec A, Groundwater, 1972, 10, 32- 43.

8. Maucha R, The graphic symbolization of the chemical composition of natural waters. Hiderol, Kozlony, 1940, 29.

9. Stiff Jr H A, J Petrol Technol., 1951, 3, 15-16.

10. Balasubramanian A, Hydrogeological investigations in the Tambraparani river basin, Tamil Nadu, Ph D Thesis, University of Mysore, 1986, 345.

11. Subramanian S, Hydrogeological studies of the coastal aquifers of Tiruchendur, Tamil Nadu, Ph D Thesis, Manonmaniam Sundaranar University, Thirunelveli, 1994, 75.

12. Piper A M, A graphic procedure in the geo-chemical interpretation of water analyses. USGS Groundwater Note No. 12, 1953.

13. Back W and Hanshaw B B, Advances in hydro-science, In Chemical Geohydrology, Academic Press, New York, 1965, 2, 49.

14. Wilcox L V, Classification and use of irrigation waters, US Department of Agriculture, Washington DC, 1955, 19.

15. Todd D K, Groundwater Hydrology, Wiley, New York, 1980, $2^{\text {nd }}$ Edn, 315.

16. US Salinity Laboratory Staff, Diagnosis and improvement of saline and alkali soils. US Department of Agricultural Hand Book, 1954, 60, 160.

17. Swaminathan S S and Narayanan S, Groundwater quality monitoring in Manali (Tamil Nadu). Report of Public Works Department, Chennai (Groundwater Wing), 1994, 61.

18. APHA, Standard methods for the examination of water and wastewater. (American Public Health Association), Washington DC, $20^{\text {th }}$ Edn., 1998. 


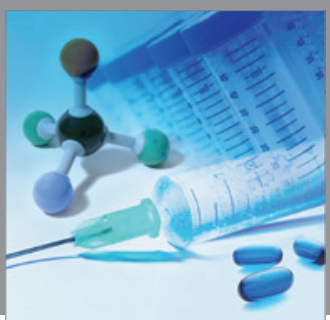

International Journal of

Medicinal Chemistry

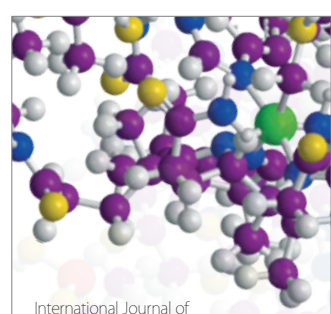

Carbohydrate Chemistry

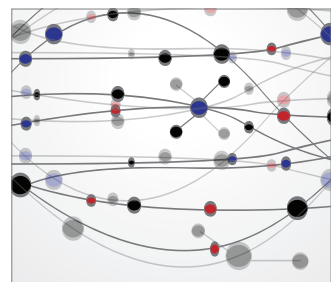

The Scientific World Journal
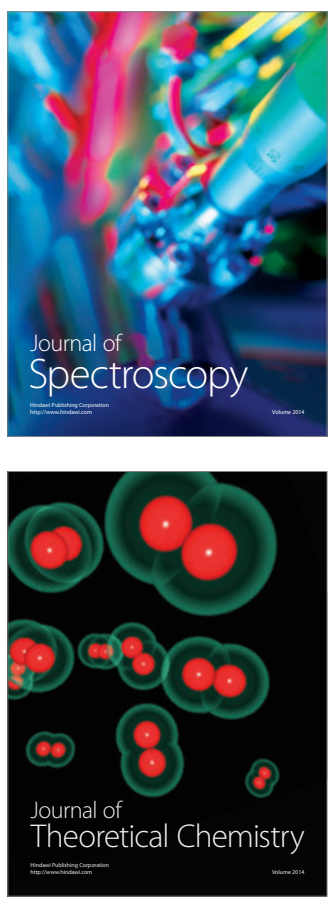
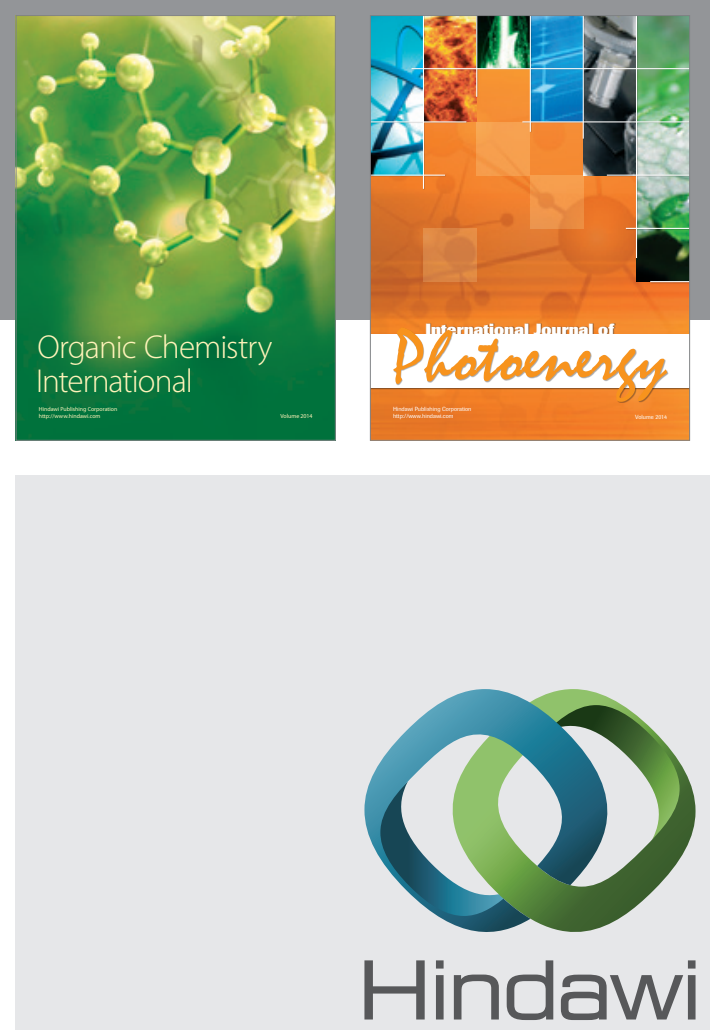

Submit your manuscripts at

http://www.hindawi.com
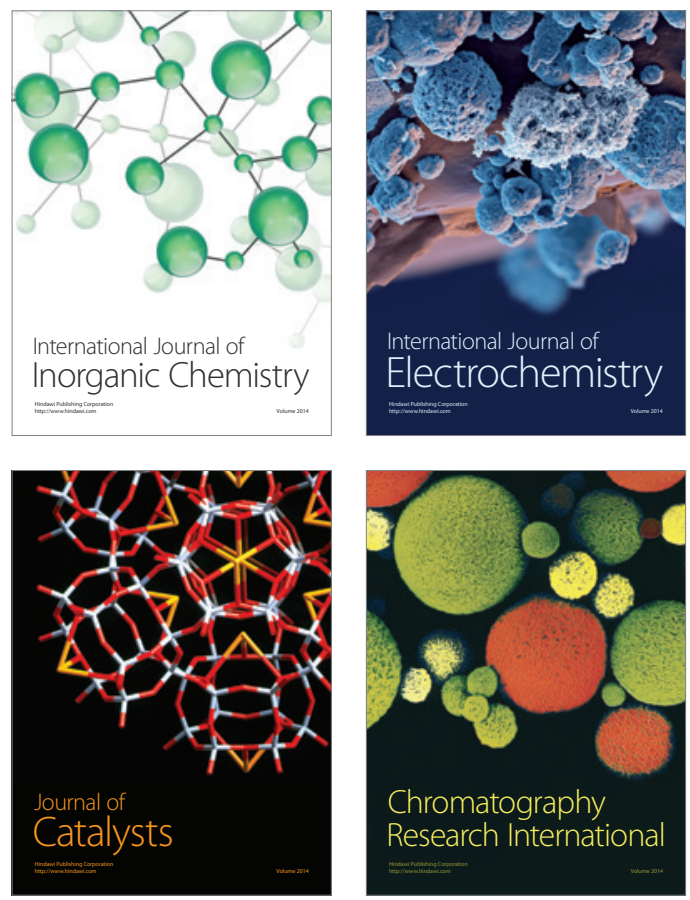
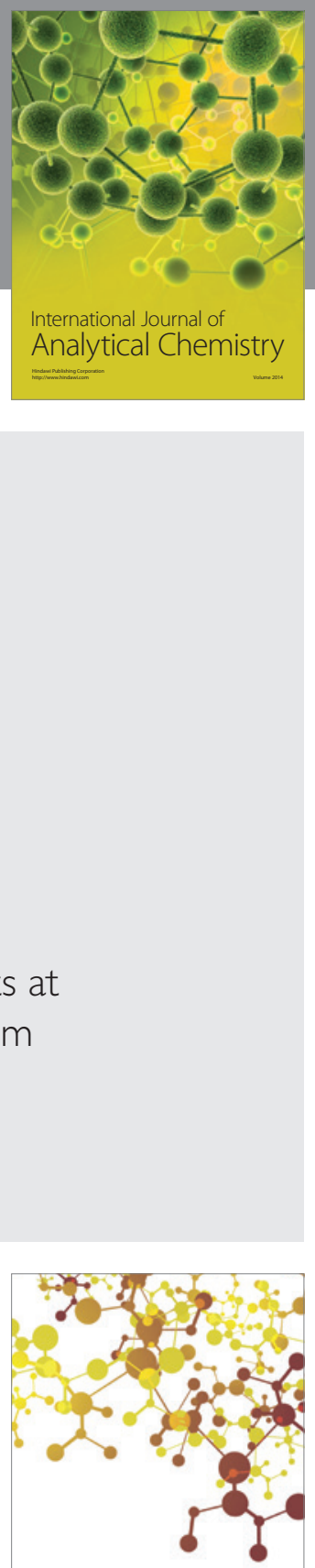

Journal of

Applied Chemistry
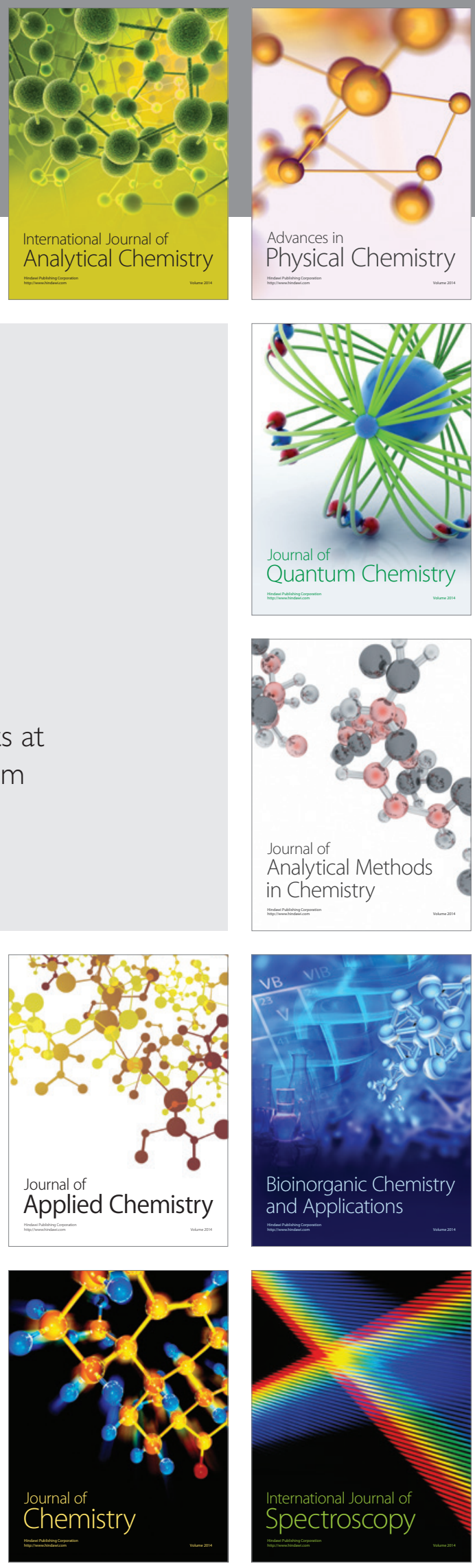